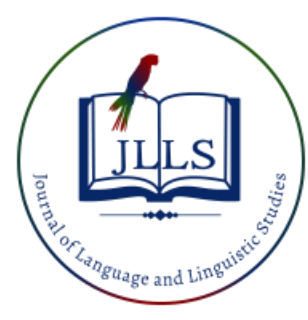

Available online at www.jlls.org

JOURNAL OF LANGUAGE AND LINGUISTIC STUDIES

ISSN: 1305-578X

Journal of Language and Linguistic Studies, 16(3), 1547-1561; 2020

\title{
Determination of errors in the writing samples of Turkish bilingual students studying in Dutch (the case of Rotterdam)
}

\author{
Vedat Halitoglu a 1 iD \\ ${ }^{a}$ Alanya Alaaddin Keykubat University, Antalya, Turkey

\section{APA Citation:}

Halitoglu, V. (2020). Determination of errors in the writing samples of bilingual students studying in Dutch (the case of Rotterdam). Journal of Language and Linguistic Studies, 16(3), 1547-1561.

Submission Date:08/04/2020

Acceptance Date: $14 / 07 / 2020$

\begin{abstract}
Many people from Turkey emigrated to European countries as a result of the bilateral agreements signed between Turkey and related countries after the 1950s. The temporary travels to these countries left their place to permanent settlements, and the Turkish children living there were faced with the danger of alienation from their mother tongue and culture in time. Many academic studies have emphasized that these children who experience L1 acquisition and learning problems will also have difficulties in learning a second language (L2), and consequently their academic achievement will be adversely affected by this situation. The data of the study were obtained from the analysis of the writing samples in which 14 students who studied in various schools in the city of Rotterdam in the Netherlands, one of the countries receiving migration, responded to two open-ended questions. In the study, within the scope of qualitative research, document analysis method was employed. During data analysis, errors were categorized in line with error analysis steps proposed by Corder (1973) and according to the codes created during the analysis process. As a result of word count in the documents, out of a 3,053-word data set, 2,676 errors were identified in total. It was determined that errors mainly occurred under the headings of deficiency in learning the mother tongue (80.79\%), word transfer from L2 to L1(6.05\%), writing according to L2 syntax (4.93\%), and mixed language use $(2.8 \%)$. Besides, letter or syllabus omission-addition in writing $(5.36 \%)$ were determined to be errors resulting from writing as one hears it. Based on writing samples, it was concluded that the number of errors was too high, and that there was a great need for learning and practicing mother tongue, including writing skills.
\end{abstract}

(C) 2020 JLLS and the Authors - Published by JLLS.

Keywords: writing; bilingualism; Dutch; Turkish

\section{Introduction}

Examining the writing samples of multilingual and bilingual children requires a multi-faceted approach. Just as it is not possible to handle bilingualism independently from mother tongue, it is impossible to consider L2 independently from mother tongue.

\footnotetext{
1 Corresponding author.

E-mail address: vedat.halitoglu@alanya.edu.tr
} 


\subsection{Mother Tongue}

Mother tongue is indicative of an individual's belonging. It is one of the essential elements in building his/her culture and personality. Many definitions of mother tongue have been made by various researchers, and it is possible to summarize them in the definition made by Kangass \& Phillipson (as cited in Kecskes \& Papp, 2009) in 1989:

$>$ The language learned from the mother

$>$ The first language learned without any conscious effort

$>$ The language stronger than all other languages in all phases of life

$>$ The dominant language of the place of residence

$>$ The language most frequently used by someone

$>$ More positive and effective language one has

The acquisition of the mother tongue in the family or the environment and the following mother tongue teaching processes are crucial for a child. Any failure to execute these processes as they should be posing an extremely damaging situation in terms of affecting the child's level of understanding and expression. The learning processes of the second language of individuals who have completed the mother tongue development process in a qualified manner are positively affected as well. Since an individual who has acquired his/her mother tongue well transfers many issues about L1 to the new language learning process while learning L2 (Denizer, 2017.) Therefore, it is possible to say the mother tongue may have a direct or indirect effect on the second language learning process (Yadav, 2014). Recently, plenty of research has been conducted in the literature on the use of mother tongue in the classroom during the second language teaching process or in multilingual classes, and widespread opinions that suppress or prohibit mother tongue use have gradually been altered (Littlewoods \& Yu, 2011; He, 2012; Mahmutoglu \& K1cır, 2013; Paker \& Karaagac, 2015.) This is because it is noted that students can comprehend many grammatical structures more easily due to similarities in their mother tongue while learning a new language (Yu \& Ren, 2013.) Besides, it can be said that a qualified mother tongue learning process has a positive effect on comprehension and understanding in the learning process of the new language (Altmisdort, 2016; Iqbal, 2016.) It is also known that the mother tongue has a positive impact on metacognitive thinking processes, literacy process in the second language and school success (Oluwole, 2008; Karsli \& Karakelle, 2018; Natalia \& Christina, 2019.) Due to the contribution of mother tongue to understanding and its effect on learning, it is necessary to support mother tongue learning and make it an essential part of language learning and even the entire learning process. Contrary to monolingual approaches that ignore the mother tongue and emphasize only one language, strategies that emphasize the mother tongue and incorporate it into the learning processes such as translanguaging are thought to contribute to the social, cognitive and linguistic development of students (Kramsch \& Huffmaster, 2015; Blackledge \& Creese, 2017; Zhu Hua \& Lyons, 2017; Wei, 2018.)

\subsection{Types and Models of Bilingualism}

When the mother tongue is learned and used together with another language or other languages, multilingualism or bilingualism develops. Bilingualism is defined in the Turkish dictionary as "Having two separate languages or having the competence and skill to read and write in two separate languages" (TDK, 2011, p. 947). However, many definitions of bilingualism have been established, and many ideas have been put forward on this subject for a long time. There are sociological, psychological, cultural and linguistic approaches within these definitions. Within these definitions, it is seen that those who adopt a linguistic approach make many alternative definitions (Bloomfield, 1933; Hornby, Macnamara, 1967; 1977; Hakuta \& Garcia, 1989; Oksaar, 1992; Valdez \& Figueroa, 1994; Aksan, 1998; Brumfit \& 
Byram, 2000; Hammers \& Blanc, 2004.) These definitions differ according to the level of competence in languages, language functionality, language learning duration, number of languages, and skill levels covered. Based on all these definitions, it is possible to express bilingualism as the situation where the second language acquired as a result of acquisition in the living environment or through studying accompanies the mother tongue. Likewise, the increase in the number of second languages creates multilingualism. Cetinkaya (2017) expresses bilingualism as the minimum status of multilingualism.

Therefore, it is possible to define bilingualism as the ability to use two languages. As regards the types of bilingualism, Bright \& McGregor (1970, as cited in Olusoji, 2013) discuss three types of bilingualism: coordinated bilingualism, compound bilingualism, and late bilingualism.

Coordinated Bilingualism: In this type of bilingualism, the mother and the father speak two separate languages. For example, while the mother speaks Dutch, the father speaks Turkish. The mother and the father speak with their children in their mother tongues. The child gains competence in both language systems and internalizes them.

Compound Bilingualism: This is the situation where the child is under the influence of both languages. For example, both parents speak two languages and communicate with their children in both languages. The child is far from gaining command of the specifics of both languages. For example, the mother and the father speaks with their children in both Dutch and Turkish. While doing so, they alternate between languages.

Late Bilingualism: It is defined as the opposite of early bilingualism. In this type, bilingualism develops after the child has passed the critical period of learning a language. The individual learns the language through exposure in the society.

The students included in the study exemplify all the three types of bilingualism mentioned above.

\subsection{Error Analysis (Written Study Areas)}

Brown (2001) defines writing as a complex system that necessitates thinking, preparing a draft and revision. This system follows a course from sounds to words, from words to sentences. Each language has its own system of rules related to this development process. They are not random and are evaluated in several disciplines.

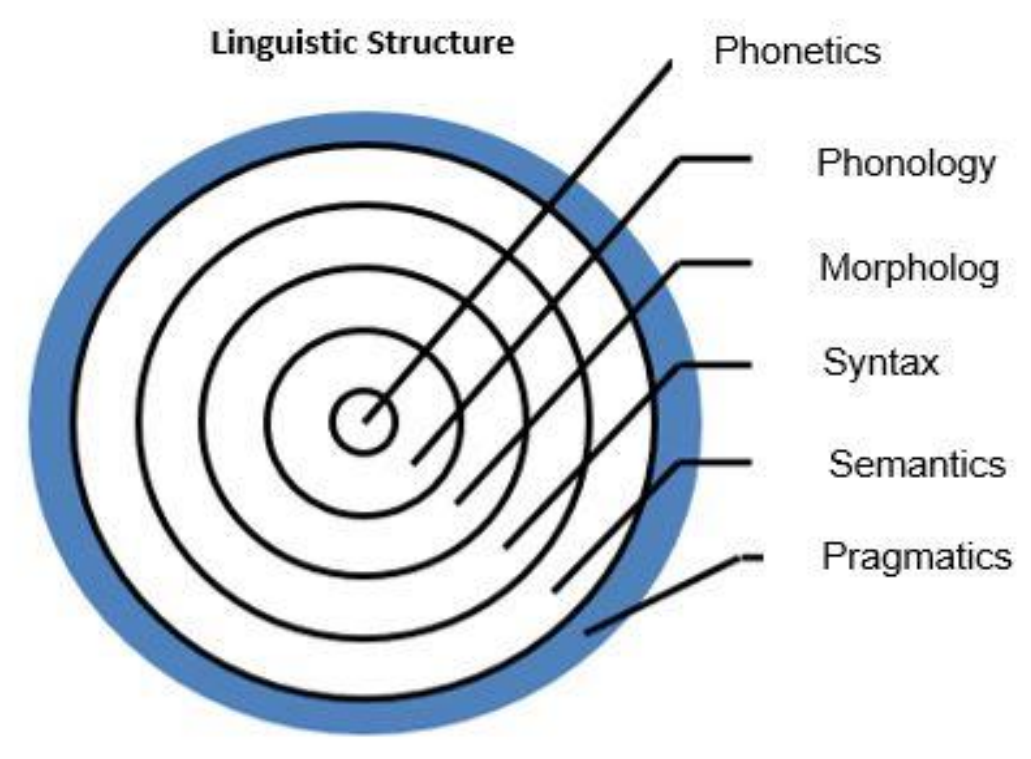

Figure 1. Adapted from J. Thomas \& Cook (2005). 
Before performing error analysis, it is necessary to mention the concepts of error and mistake. According to Ellis (1997), a student makes an error because of a knowledge s/he is not aware of. Mistake, on the other hand, is a momentary slip which can be corrected. Thus, while errors are systematic, mistakes are not. In the study, the focus was on systematic errors. Corder (1967) stated that linguistic errors are significant. Errors show the teacher what to teach. They tell the researchers how learning will be sustained and allow them to test their hypotheses based on the interpretation of errors. James (1998) emphasizes that error analysis provides information about what students have learned and what they have missed, and he argues that when they are explained and identified, errors can be reduced. Moreover, through error analysis, teachers obtain feedback on the course and accordingly plan what subjects they should focus on (Khansir, 2012).

While performing error analysis, it should be considered that errors have two essential sources as intralingual and interlingual sources. While intralingual errors result from the learner's lack of knowledge regarding the target language (Kaweera, 2013), interlanguage errors can be defined as errors caused by the influence of the mother tongue on the target language to be learned (Richard, 1971). In this situation, since the linguistic principles of the mother tongue are quite different from those of the target language, the learner finds it difficult to learn the new language and starts to transfer the rules and structures of the mother tongue onto the target language (Krashen, 1981).

A variety of error analyses can be mentioned in linguistic sources. Among these analyses, the error analysis category, which was also used in the study, is a categorization method which was developed by Corder (1973) and used and improved by Dulay, Burt \& Krashen (1982), Brown (2000):

$>$ Omission: Lack of an element that should be present

$>$ Addition: Presence of more elements than necessary

$>$ Misinformation: Use of wrong structures and sounds

$>$ Misordering: Wrong position of a sound or sound cluster

\section{Method}

\subsection{Research Design}

Within the scope of the research, answers to the following question were sought:

$>$ What are the errors present in the writing samples of the bilingual Turkish children living in Rotterdam written in their mother tongue and how often are these errors made?

The study was conducted using document analysis technique, which is one the qualitative research designs. Document analysis includes the analysis of written materials which consist of information about the phenomenon or phenomena to be researched. "In document analysis, the main purpose is to analyse written materials that contain information about the phenomenon or phenomena to be studied" Yildirim \& Simsek, 2006). Document analysis is made through analysis of documents to obtain data related to the purposes of the research (Cepni, 2010).

\subsection{Data Collection}

The data of the research consisted of writing paper samples in which 14 students studying in different schools of Rotterdam, Holland responded to two open-ended questions. As writing task, the prompts "Can you tell us about your school" and "What do you do in your summer vacations?" were given. The open-ended questions were made up of subjects which the students could easily answer. In addition, the participants were asked some questions about their demographic and linguistic characteristics. The 
written texts mentioned were considered to be a "document" for the research data. These documents were numbered from 1 to 14 . When all the words in the documents were counted, it was seen that a data set of 3053 words were obtained.

\subsection{Study Group and Participants}

Detailed information about the study group is presented below.

\subsubsection{Demographic Characteristics}

The study group was made up of 14 students studying in the city of Rotterdam in the Netherlands. Two of the students were female, and 12 were male. The table below shows the gender distribution of the participants

Table 1. Gender Distribution of the Participants

\begin{tabular}{ccc}
\hline Gender & Frequency & Percent \\
\hline Male & 12 & 85.7 \\
Female & 2 & 14.3 \\
Total & 14 & 100.0 \\
\hline
\end{tabular}

14 students participated in writing-focused research. In line with research ethics, the names of the participants were not used. Therefore, the writing papers of the students were numbered from 1 to 14 , and " $\mathrm{D}$ " of the word document were put in front of the numbers. The information about the students' age and documents are presented in the following table.

Table 2. Participants' Age and Document Information

\begin{tabular}{cccc}
\hline Ages & Frequency & Percent & Document Numbers \\
\hline 10 & 4 & 28.57 & $2,7,9,11$ \\
11 & 5 & 35.71 & $1,6,8,12,14$ \\
12 & 5 & 35.71 & $3,4,5,10,13$ \\
Total & 14 & 100.0 & \\
\hline
\end{tabular}

\subsubsection{The Status of Language Use}

The following information about the participants regarding the use of mother tongue and L2 within the family was obtained.

Table 3. The Participants' Language Use Status

\begin{tabular}{cccc}
\hline Language Usage & Frequency & Percent & Document Numbers \\
\hline Only Dutch & 1 & 7.1 & 5 \\
Only Turkish & 5 & 35.7 & $2,3,4,6,7$ \\
Dutch and Turkish & 8 & 57.1 & $1,8,9,10,11,12,13,14$ \\
Total & 14 & 100.0 & \\
\hline
\end{tabular}

\subsection{Data Analysis}

Corder (1974) proposed five steps in error analysis, which are:
1- Collection of a sample
2- Identification of errors
3- Description of errors
4- Explanation of errors
5- Evaluation of errors 
In the analysis of the data, the error analysis steps mentioned above were employed. The data analysis of the research included two stages in general:

Stage 1: All data obtained were subjected to content analysis. Content analysis enables to classify the indicators (in order to reveal what judgements these indicators involve) under the light of clearly formulated rules and to evaluate the judgements made by the researcher as a scientific report (Janis, 1949). The errors that were identified were noted down together with explanations meticulously. The most frequent errors were grouped into headings and their frequencies were calculated.

Stage 2: Notable examples regarding the error groups were determined, commented by the researcher.

When the errors were subjected to content analysis, they were gathered under two headings as intralingual (mother tongue) errors and errors developing as a result of the influence of L2. Linguistic errors in Turkish were classified as omission, addition, and misinformation. The errors resulting from the influence of L2 (Dutch) were categorized as blending, loan words, and syntactic errors. According to Odlin (1989), the syntactic, phonetic and morphological features of the mother tongue have a great influence on the production of the structure and pronunciation of the target language (as cited in Badawi, 2012).

\section{Results}

The documents of the participants were numbered from 1 to 14 and subjected to content analysis. The errors determined in student papers are summarized in the table below.

Table 4. The Number of Lexical Errors, Their Category, Frequency, Percentage and Rank

\begin{tabular}{|c|c|c|c|}
\hline Types of Errors & Frequency & Percentage & Rank \\
\hline \multicolumn{4}{|c|}{ Intralingual (Turkish) Errors } \\
\hline \multicolumn{4}{|l|}{ Ommision } \\
\hline phonological & 88 & 3,28 & 9 \\
\hline morphological & 36 & 1,34 & 14 \\
\hline \multicolumn{4}{|l|}{ Addition } \\
\hline phonological & 14 & 0,52 & 15 \\
\hline morphological & 6 & 0,22 & 16 \\
\hline \multicolumn{4}{|l|}{ Misinformation } \\
\hline vocal harmony & 803 & 30 & 1 \\
\hline Turkish letter writing & 566 & 21,15 & 2 \\
\hline punctuation & 227 & 8,48 & 3 \\
\hline consonant harmony & 158 & 5,9 & 5 \\
\hline Spelling & 102 & 3,81 & 7 \\
\hline consonant softening & 98 & 3,66 & 8 \\
\hline Accent-dialect & 80 & 2,98 & 10 \\
\hline capitalization & 78 & 2,91 & 11 \\
\hline alternation of vowel & 51 & 1,9 & 13 \\
\hline \multicolumn{4}{|c|}{ Interlingual (Turkish-Dutch) Errors } \\
\hline loan words & 162 & 6,05 & 4 \\
\hline syntax & 132 & 4,93 & 6 \\
\hline Blending & 75 & 2,8 & 12 \\
\hline Total & 2676 & 100 & 16 \\
\hline
\end{tabular}


When the table above is examined, it is seen that the most frequent error is related to the wovel harmony rule problems specific to Turkish (30\%). In the second place are the problems related to the spelling of letters specific to Turkish $(21.15 \%)$. The use of punctuations marks $(8.48 \%)$ occupies the third rank among the th emost frequent errors. Other that these errors, we can see errors such as loan words between languages $(6.05 \%)$, consonant harmony (5.9\%), syntax $(4.93 \%)$, spelling $(3.81 \%)$, consonant softening (3.66\%), phonetic omsission (3.28\%), local dialect features (2.98\%), capitalization (2.91\%), blending (2.8\%), wovel change (1.90\%), morphological omission (1.34\%), phonetic addition $(0.52 \%)$, and morphological addition $(0.22 \%)$. The most frequent errors are discussed below with examples.

\subsection{Vocal Harmony Errors}

It is seen that the rule specific to Turkish requiring that a back wovel $(\mathrm{a}, 1, \mathrm{u}, \mathrm{o})$ should follow a back wovel and a front wovel (e,i,ö,ü) should be followed by a front wovel in a word is not obeyed (30\%). It is believed that this situation stems from lack of knowledge and practice.

Example 1: “çocüklari gormedim neden...” (çocukları görmedim neden...) (D 3)

Example 2: “...yuzmeyi seviyorum.”(...yüzmeyi seviyorum.) (D10)

Many similar examples can be given to this phenomenon such as "disarda, olmadigi, kiziyorum..." (dışarıda, olmadığı, kızıyorum...). It is seen that all students (D1-D4) made errors in this issue.

\subsection{Turkish Letter Writing Errors}

Turkish letter writing stands out as the second most frequent error $(21.15 \%)$. When the average of the students are examined, it is seen that although they are at the age of secondary education (10-12 years old), they are quite imcompetent about Turkish letters. Particularly, errors are concentrated around the letters that exist in Turkish $(1, \breve{g}, c ̧, u ̈, o ̈, s ̧)$ without a counterpart in Dutch. Students experienced confusion about writing these letters and made quite a lot of errors in this area.

Example 3: “...cok gorduk.” (...çok gördük.) (D7)

It is seen that students did not use the letters in Turkish and preferred to use similar letters in the second language instead. It is believed that some students were confused due to lack of knowledge about Turkish letters.

Example 4: "Camiler dolu cok sicak yani..." (Camiler dolu çok sıcak yani...) (D1)

The student in question misspelled the words "Turkiyede, yuzme, cok, 1yi ... etc.", but spelled the words "bir, köy, güzel, deniz..." correctly.

Especially many errors are present regarding the spelling of the words "Türkiye and Türkçe" in several documents (D1, D3, D4, D5, D6, D7, D8, D9, D10, D12, D13, D14).

Example 5: Evet her sene gidiyorum Turkiyeye ve Turkce... (Evet, her sene gidiyorum Türkiye'ye ve Türkçe....) (D 4)

Similar to the examples above, students made frequent errors in the spelling of many words regarding the letter "ü" such as "guzel, buyuk, cunku, gözluk ..." Examples of words in which this letter was misspelled by all students were determined. Their names and surnames were spelled by students in the form they were spelled in Dutch (D1, D2, D3, D4, D6, D7, D9, D10, D11, D13, D14).

Example 6: “... sogut”, “...gokce”, “huseyin...” (... Söğüt, .... Gökçe, Hüseyin ...) 


\subsection{Punctuation Errors}

Punctuation errors were also among the most frequent errors (8.48\%). It is noteworthy that studnets made such errors despite many common rules in both languages. Furthermore, it was observed that punctuations marks were used very little in the documents. In some papers, no punctuation marks were used (D1, D2, D8, D11, D13). It is believed that even though similar punctuatiom marks existed in the second language (Dutch), students did not learn these marks sufficiently or they were not aware of the existence and use of these punctuation marks in Turkish. Problems regarding the use of exclamation mark and other punctuatiom marks were observed.

Example 7: “...bazen beni akip gidiyo!” (Bazen beni ekip gidiyor.) (D 12)

Some examples related to separating inflectional suffixes added to proper names with apostrophe were detected.

Example 8: "Ben Turkiyeyi konyadan izlıyorum..." (Ben Türkiye'yi Konya'dan izliyorum) (D 4)

However, it is seen that full stop and comma marks were used correctly. It is noteworthy that errors are very few in the use of these punctuation marks.

Example 9: "Humeyra, Camille, Mavrits...” (doğru yazım) (D 9)

\subsection{Loan Words Errors}

Students occasionally used their second language (Dutch) while writing in their moaher tongue (Turkish), which was very common (6.05\%). Sometimes, they used Dutch equivalent without making any changes for a word in Turkish they did not know the meaning of. Students in this category of errors werer those in whose houses only Dutch or Dutch and Turkish are spoken.

Example 10: “... ama çok illegaal var...” (... ama çok suçlu var...) (D13)

Example 11: “...spelling seviyorum.” ( ... imlayı seviyorum.) (D5)

In some cases, when they wanted to use an unfamiliar word in their mother tongue, students wrote the equivalent of that word in the secind language (Dutch) by adapting its pronunciation in Dutch to the sound structure of their mother tongue.

Example 12: “...zıveme çok gittik...” [yüzmeye çok gittik (Turkish), we gingen zwemmen (Dutch)] (D8)

Some other students preferred to write some common words in Turkish and Dutch in the forms in Dutch.

Example 13: "Turkiyede hotel cok...” (Türkiye'de otel çok...) (D9)

\subsection{Consonant Harmony Errors}

A similar situation to the wovel harmony in Turkish is also valid for the consonants. Words ending with strong consonants (f, s, t, k, ç, ş, h, p) take suffixes starting with srong consonants. Likewise, words ending with soft consonants (b, c, d, g, ğ, j, l, m, n, r, v, y, z) take suffixes starting with soft consonants. It is seen that studnets made many errors (\%5.9) resulting from lack of knowledge in this issue.

Example 14: ...matematik seviorum ve ingilizçe (...matematik seviyorum ve İngilizce) D (5)

Example 15: ... tenefüsde dısari cıkıyok... (...teneffüste dışarı çıkıyoruz) D (6) 


\subsection{Syntax}

While the syntax of Turkish foloows the order of subject+object+verb, the syntax in Dutch is in the form of subject+verb+object. Due to this syntactic difference, it is seen that students formed inverted sentences $(4.93 \%)$ while writing similar to the syntax of the second language (Dutch).

Example 16: “... beni çağırıyorlar her zaman.” (...beni her zaman çağırıyorlar.) (D8)

Example 17: “...evet, her sene gidiyorum Turkiyeye.” (evet, her sene Türkiye’ye gidiyorum.) (D1)

\subsection{Spelling Errors}

It was observed that student made errors related to some spelling rules $(3.81 \%)$. Particularly, they commonly did not use capitalization of the first letter of proper nouns.

Example 18: “...akrabam humeyra arada sırade yardım ediyor.” (akrabam Humeyra arada sirada yardım ediyor.) (D10)

They were also confused and made errors related to writing the conjunction "de, da" separately from the noun and the suffix "de, da" contiguous to the noun.

Example 19: “...ama köy de oturuyorum.” (...ama köyde oturuyorum.) (D2)

\subsection{Consonant Softening Errors}

In Turkish, when a suffix starting with a wovel is added to a word ending with the strong consonants (p, ç, t, k), these letters at the end of the word are changed into (b, c, d, g ( $\mathrm{g})$ ). The precentage of violation of this rule was determiend to be $3.66 \%$.

Example 20: "sokaka hergun cıkıyok hep oyniyos." (sokağa her gün çıkıyoruz hep oynuyoruz (D14)

\subsection{Phonological Omission}

It is seen that phonologicall (3.28\%) and morphological (1.34\%) omissions were made mostly in writing exactly what one hears. It is thought that such errors resulted from learning Turkish through hearing rather than through formal education and written material.

Example 21: “Ö_retmenler bize kıziolar” (Öğretmenler bize kızıyorlar.) (D1)

Many examples are present in the writing of a lot of words: "orda, ole, saklayabilio, kokyo vb." (orada, öyle, saklayabiliyor, kokuyor vb.).

\subsection{Accent-Dialect}

It was determined that almost all the students learned their mother tongue through what they have heard in the family rather than written and visual publishing and transfered this knowledge to writing. In this case, the region of Turkey where the family came from and dialect features of Turkish spoken in those regions were the determining factors in misspelling of the words. Therefore, deviations from standard Turkish (Istanbul dialect) (2.98\%) are observed in the writing samples of the students. This situation is very evident in some students, and the errors in question are common among those in whose houses only Turkish is spoken (D3, D6, D7).

$$
\text { Example 22: “...g gızlar okulnan çok...” (...kızlar okul ile çok...) }
$$




\subsection{Capitalization}

Errors made in the rules related to capitalization (2.91\%), which exist in many languages, were considered to have resulted from lack of knowledge. Errors in this area are common in writing names and surnames, country names, names of locations and school names.

Example 23: “... konyaliyim.” (...Konyalıyım.) (a name of city in Turkey) (D6)

\subsection{Blending}

Using the features of both languages $(2.8 \%)$ is also present in some student papers. When such examples are examined, it is seen that since especially the pronunciation of the sound " $y$ " in Turkish has an equivalent pronunciation to the sound " $\mathrm{j}$ " in Dutch, students ofted chose to use " $\mathrm{j}$ " sound of Dutch in place of "y" sound in Turkish in their writing.

Example 24: "Çanakkaleje gecen yaz..." (Çanakkale'ye geçen yaz...) ( D1)

Example 25: "Turkije'de yazlari dereje ..." (Türkiye'de yazları dereye...) (D5)

\section{Discussion}

The findings obtained from the analysis of the data retrieved through the responses of the students to the open-ended questions in their writing papers are concentrated under certain headings. It is seen that more than half of the students (51.25\%) made the most errors in letters existing in Turkish but not present in Dutch and vocal harmony. This situation is indicative of the fact that students did not recognize the letters specific to Turkish (I, ğ, ç, ü, ö, ş) or that they did not learn them appropriately. The level of errors detected in the writing samples support the need of the students for learning their mother tongue. In 11 documents, it was seen that names and surnames are misspelled, and in 12 of the documents, the words "Türkçe and Türkiye" were spelled incorrectly. It is notable that the students did not have awareness and knowledge about such an important issue as writing the names and Turkish correctly in terms of sense of belonging. There is a risk of alienation from the self and social environment for an individual who did not have a good command of his/her mother tongue under the influence of multilingualism and multiculturalism (Cakir, 2002). Besides, there is a significant and positive relationship between mother tongue and identity (Phinney et al., 2001). When the students' errors related to phonological-morphological addition, omission and dialect use are examined, it is seen that having learned the language through hearing $(8.34 \%)$ has a big influence. It is seen that syllables or letters are omitted and added. The errors in this category appeared as writing down exactly what one hears. Students made an effort to write the language they have heard as well as resorting to dialects other than standard language use. The mother tongue use of the family as it is spoken in the region of Turkey they came from was totally transferred to the child. The educational status of the families are low since they are workers and mostly came from the villages in Turkey (Sevinc, 1999). In this case, students need to be exposed to the oral and written use of the standard language, which is not available in the family environment. Teaching of the mother tongue has an important role in terms of meeting this need. However, in contrast to other European countries (Germany, France, Belgium etc.), mother tongue education activities are low in number in the Netherlands (Bingol \& Ozdemir, 2014). On the other hand, some scientists advocate this situation. Driessen (1997) argues that teaching of mother tongue in state schools in the Netherlands (primary and secondary schools) must be forbidden as this education is insufficient and deficient. As a result of such arguments, mother tongue educational activities, which were previously provided in the primary and secondary schools in the Netherlands, were banned as of 2004 and classes were terminated. Besides, the Turkish teachers who provide mother tongue education 
for the immigrant children are not allowed to work in the Netherlands. However, Kutlay (2016) opposes to this situation by saying that not providing mother tongue education cannot be justified by claiming that the quality of education is low. Instead, he emphasizes that Turkish teachers should be educated in the Dutch education system and Turkish education should be provided. Many researchers also support this stance /Aytan et al., 2019). Furthermore, the presence of immigrant teachers in the education system is important in terms of reflecting the immigrants' perspective of the world (Leeman \& Reid, 2006). It is seen that students cannot write the Turkish words other than colloquial language. The answers to the questions consist of simple and short sentences. Lexical variety and range are deficient and at daily language level. Particularly, Turkish equivalents of some terminological words such as "taal, spelling etc." in school and education terminology could not be written because it is difficult to learn such terminology in the family environment. In this case, students resorted to using Dutch equivalents (6.05\%). Knowledge and practice deficiency is observed in all documents in terms of writing, which suggests that the second language (Dutch) cannot be expected to be learned appropriately. The reason for this is that having received a quality education of mother tongue facilitates learning a second language (L2) by the individuals. Language skills that have been acquired completely can also be transferred to the second language (Cho, 2000; Makalela, 2005, Heugh et al., 2007). According to Aebersold \& Field (1997), the more an individual is in his/her learning the mother tongue, the more flexible, adaptive, inquisitive and monitoring reader s/he becomes in the second language. In an education model study conducted by Verhoeven, who is known with literacy studies he made, he concluded that children who receive mother tongue education along with second language education (blended model) do not experience any difficulties in terms of literacy even if they start Dutch education at later ages, and that they become more successful in reading and writing compared to the children who receive only Dutch education. Therefore, achievement or failure in mother tongue has an influence on second language, and indirectly on school achievement.

\section{Conclusion}

\subsection{Recommendations}

- Educational activities for parents on the importance of mother tongue education should be provided by authorities

- Writing skill should be supported strongly together with other language learning areas

- Students should be provided with better contents and examples in standard language (Istanbul dialect)

- Mother tongue education should be provided in primary and secondary schools in the Netherlands on an elective or compulsory basis.

- Support on issues such as teacher, material etc. should be required from Turkey for mother tongue education.

\section{Ethics Committee Approval}

The author(s) confirm(s) that the study does not need ethics committee approval according to the research integrity rules in their country (Date of Confirmation: August 18, 2020). 


\section{References}

Aebersold, J., M. L. Field. (1997). From reading to reading teacher ussues and strategies for second language classroom. Cambridge: Cambridge University Publishing.

Aksan, D. (1998). Her yönüyle dil ana çizgileri ile dilbilim. TDK Yayınları, Ankara.

Altmisdort, G. (2016). The effects of 12 reading skills on 11 reading skills through transfer. English Language Teaching, 9(9), 28-35.

Aytan, T., Baskapan, A., Uysal, G. (2018). Avrupalı Türkler ana dili eğitimi çalıştayları üzerine bir değerlendirme. Turkophone, 5(2), 16-34.

Badawi, K. (2012). An analysis of phonetic, morphological and syntactic errors in English: a case study of saudi ba students at King Khalid University. International Journal of Social Science and Humanity, 2(6), 536-538.

Bingol, A. S., Ozdemir, M. Ç. (2014). Almanya ve Hollanda'da Türk göçmen işçi çocuklarına uygulanan eğitim politikaları. Journal of Turkish Educational Sciences, 12(2), 134-157.

Blackledge, A., Creese, A. (2017). Translanguaging in mobility. In S. Canagarajah (Ed.), The Routledge Handbook of Migration and Language (31-46). Routledge: London/New York.

Brown, H. D. (2000). Principles of language learning and teaching. New York: Pearson Education.

Brown, H. D. (2001). Teaching by principle. San Fransisco: Second Edition.

Brumfit, C., Byram, M. (editors) et al. (2000). Routledge Encyclopedia of Language Teaching and learning. UK: Psychology Press.

Cakır, M. (2002). Almanya'daki çok kültürlü ortamlarda Türkçenin ana dili olarak kullanımı. Anadolu Üniversitesi Sosyal Bilimler Dergisi, 1, 39-58.

Cepni, S. (2018). Araştırma ve proje çalışmalarına giriş, Trabzon: Pegem Yayınevi.

Cho, G. (2000). The role of heritage language in social interactions and relationships: Reflections from a language minority group. Bilingual Research Journal, 24 (4), 369-384.

Corder, P. (1967). The significance of learners' errors. International Review of Applied Linguistics, 5, 161-170.

Cetinkaya, S. (2017). Çok dillilik ve kimlik. Uluslararası Sosyal Araştırmalar Dergisi, 10(50), 371-377.

Denizer, E. N. (2017). Does mother tongue interfere in second language learning? Journal of Foreign Language Education and Technology, 2(1), 39-54.

Driessen, G. (1997). From mother tongue to foreign language: prospects for minority language education in the Netherlands. In perspectives on foreign language policy: studies in honour of Theo Van Els, T. Bongaerts and K. De Bot ( eds.). Amsterdam: John Benjamins Publishing.

Dulay, H., Burt, M., Krashen, S. (1982). Language two. New York: Oxford University Press.

Ellis, R. (1997). Second language acquisition. Oxford University Press: Oxford

Hakuta, K.; Garcia, E. (1989). American psychologist bilingualism and education University of California: Santa Cruz. 
Hamers, J. F., Blanc M. H. A. (2004). Bilinguality and bilingualism (2nd ed.). Cambridge: Cambridge University Press.

He, A. E. (2012). Systematic use of mother tongue as learning/teaching resources in target language instruction. Multilingual Edication. 2, 1-15.

Heugh, K., Diedericks, G., Prinsloo, C. H., Herbst, D., Winnaar, L. (2007). Assessment of the language and mathematics skills of grade 8 learners in the Western Cape in 2006. Pretoria: Human Sciences Research Council.

Hornby, P. A. (1977). Bilingualism: psychological, social, and educational implications. New York: Academic Press, Inc.

Hua, Z., Wei, L. Lyons, A. (2017). Polish shop(ping) as translanguaging space. Social Semiotics, 27(4), 411-433.

Iqbal, Y. (2016). The influence of mother tongue on learning a foreign language in the Kingdome of Bahrain. European Journal of English Language, Linguistics and Literature, 3(2). 44-51

James, C. (1998). Errors in language learning and use: exploring error analysis. New York: Routledge.

Janis, L. (1949). The problem of validating content analysis. H.D. Lasswell ve ark (eds), the language of politics: studies in quantitative semantics, New York: George Stewart.

Karsli, Y., Karakelle, S . (2018). Bilişsel esneklik, iki dillilik ve üst bilişsel kararlar arasındaki bağlantılar. Psikoloji Çalı̧̧maları, 38(2), 171-200.

Kaweera, C. (2013). Writing error: A review of interlingual and intralingual interference in EFL context. English Language Teaching, 6, 9-18.

Kecskes, I., Papp. T. (2009). Foregin language and mother language. Taylor\& Francis e-Library

Khansir, A. (2012). Error analysis and second language acquisition, Theory and Practice in Language Studies, 2 (5), 1027-1032.

Kramsch, C., Huffmaster, M. (2015). Multilingual practices in foreign language study. In J. Cenoz, D. Gorter (Eds.) Multilingual Education: Between language learning and translanguaging (114 136). UK: Cambridge University Press.

Krashen, S. D. (1981). Second language acquisition and second language learning US: Pergamon Press Inc.

Leeman, Y., Reid, C. (2006). Multi/intercultural education in Australia and the Netherlands. Compare, 36(1), 57-72.

Littlewood W., Yu B. H. (2011). First language and target language in the foreign language classroom. Language Teaching, 44(1), 64-77.

Macnamara, J. (1967). The Bilingual's linguistic performance, a psychological overview. Journal of Social Issue, 23, 58-77.

Mahmutoğlu, H., Kıcır, Z. (2013). The Use of mother tongue in efl classrooms. EUL Journal of Social Sciences, 4(1), 49-72. 
Makalela, L. (2005). We speak eleven tongues: reconstructing multilingualism South Africa. In B. Brock-Utne, R. Hopson (Eds.), languages of instruction for African emancipation: focus on postcolonial contexts and considerations, Cape Town/Dar-es-salam: CASAS and Mkuki n Nyota Publishers.

Natalia, G., Christina, H. (2019). The Impact of mother tongue instruction on the development of biliteracy: evidence from Somali-Swedish bilinguals. Applied Linguistics, 40(1), 108-131.

Oksaar, E. (1992). Mehrsprachigkeit. Sprachreport, IDS Mannheim.

Olusoji, O. A. (2013). Effects of bilingualism on the essays of Yoruba/English bilinguals. European Journal of Arts and Humanities, 1(1), 36-47.

Oluwole, D. A. (2008). The Impact of mother tongue on students' achievement in English language in junior secondary certificate examination in Western Nigeria. Journal of Sociological Society, 12(1), 41-49.

Paker, T., Karaagac, Ö. (2015). The use and functions of mother tongue in efl classes. Procedia Social And Behavioral Sciences, 199, 111-119.

Phinney, J. S., Romero, I., Nava, M. et al. (2001). The role of language, parents, and peers in ethnic identity among adolescents in immigrant families. Journal of Youth and Adolescence 30, 135 153.

Richards, J. C. (1971). A Non- contrastive approach to error analysis. Journal of ELT. 25, 204-219.

Sevinc, İ. (1999). Hollanda'daki Türk çocuklarının eğitim sorunları ve yoğunlaşma okulları. Yayımlanmamış Yüksek Lisans Tezi. Ankara Üniversitesi, Sosyal Bilimler Enstitüsü, Felsefe ve Din Bilimleri, Din Eğitimi Anabilim Dalı.

Thomas, J., K. A. Cook (2005). Illuminating the path: the research and development agenda for visual analytics, IEEE CS Press.

Valdez, G., Figueora, R. A. (1994). Bilingual and testing: a special case of bias. Norwood, NJ: Ablex Publishing Corp.

Verhoeven, L. (1991). Acquisition of biliteracy. AILA Review, 8, 61-74.

Wei, L. (2018). Translanguaging as a practical theory of language. Applied Linguistics, 39(1), 9-30.

Yadav, M. K. (2014). Role of mother tongue in second language learning. International Journal of Research, 1(11), 572-582.

Yagmur, K. (2006). Batı Avrupa'da Türkçe ögretiminin sorunları ve çözüm önerileri. Dil Dergisi, 31 48.

Yildirim A.; Simsek, H. (2005). Sosyal bilimlerde nitel araştırma yöntemleri (genişletilmiş 5. baskı). Ankara: Seçkin Yayıncılık

Yu, H., Ren, C. (2013). The Positive role of 11 in the acquisition of a second language. Studies in Literature and Language, 7(2), 45-48. 


\section{Hollandaca (Dutch) öğrenim gören iki dilli Türk çocuklarının yazı örneklerinde ortaya çıkan yanlışların tespiti (Roterdam örneği)}

\section{$\ddot{O} \mathbf{z}$}

Avrupa ülkelerine 1950’li yıllardan sonra Türkiye ile imzalanana iş̧̧i göçü anlaşmalarıyla birçok kişi göç etmiştir. Buralara kısa süreli gidişler yerini kalıcı yerleşmelere bırakmış ve oralarda yaşayan Türk çocukları, zaman içerisinde giderek ana dili ve kültürlerine uzaklaşma tehlikesiyle ile karşılaşmıştır. Birçok akademik çalışma, ana dili edinim ve öğrenim sorunları yaşayan çocukların ikinci dili (L2) öğrenmede güçlükler çekeceğini ve dolayısıyla bu durumda akademik başarının da olumsuz etkileneceğini vurgulamaktadır. Çalışmanın verileri söz konusu göçlerin yaşandığı ülkelerden biri olan Hollanda'nın Rotterdam şehrinde çeşitli okullarda öğrenim gören on dört çocuğun açık uçlu iki soruya verdikleri cevapları içeren yazı kâğıdı örneklerinin çözümlenmesinden oluşmaktadır. Araştırmada nitel araştırma kapsamında doküman incelemesi yöntemi esas alınmıştır. Veri çözümleme aşamasında yanlışlar, Corder'ın (1973) ifade ettiği yanlış çözümlemesi basamakları ve çözümleme sürecinde ortaya çıkan kodlara göre kategorilendirilmiştir. Dokümanlarda yapılan kelime sayımı neticesinde 3053 kelimelik bir veri setinden toplamda 2676 yanlış tespit edilmiştir. Yanlışların daha çok ana dili bilgi eksikliği (\%80.79), ikinci dilden ana diline kelime transferi (\%6.05), ikinci dilin söz dizimine göre yazma (\%4.93) ve karma dil kullanımı (\% 2.8) başlıklarında toplandığı görülmektedir. Ayrıca yazmada yapılan harf veya hece eksiltme-arttırmanın (\%5.36) duyduğu gibi yazma neticesinde ortaya çıktığı değerlendirilmiştir. Yazı örneklerinden hareketle yanlış sayısının oldukça fazla olduğu, yazma becerisini de kapsayan ana dili öğrenme ve pratiklerine büyük ihtiyaç duyulduğu sonucuna ulaşılmıştır.

Anahtar sözcükler: yazma; iki dillilik; Hollandaca; Türkçe

\section{AUTHOR BIODATA}

Vedat Halitoglu is currently working as an assistant professor at Alanya Alaaddin Keykubat University. 